БОДНАРУК М. І., доктор юридичних наук, доцент, завідувач кафедри приватного права (Чернівеиький національний університет імені Юрія Федьковича)

\section{КОЗУБ І. Г.,} кандидат юридичних наук, доцент кафедри приватного права (Чернівецький національний університет імені Юрія Федьковича)

\title{
ЩОДО ОХОРОНИ ТРУДОВИХ ПРАВ ОСІБ 3 ІНВАЛІДНІСТЮ
}

У статті проаналізовано поняття охорони та захисту трудових прав осіб з інвалідністю. Охорона трудових прав осіб з інвалідністю може розглядатися як у широкому, так і у вузькому розумінні. Беручи до уваги метод трудового права та його характерні прояви, зокрема єдність і диференціацію правового регулювання трудових відносин, охорону трудових прав осіб з інвалідністю можна диференціювати на загальну та спеціальну. Загальна встановлюється, визначається та здійснюється для особи з інвалідністю нарівні з іншими найманими працівниками. Охорона трудових прав осіб з інвалідністю є спеціальною, коли встановлюється, визначається та здійснюється тільки щодо працівників, яким встановлена група інвалідності. Враховуючи реалії сьогодення та невідповідність юридично визначеної охорони трудових прав осіб з інвалідністю з ії фактичною реалізацією на практиці, таку охорону трудових прав можна класифікувати на юридичну та фактичну.

Правовими явищами, спрямованими на недопущення порушення трудових прав працівників з інвалідністю, створення необхідних умов для їх безперешкодної ефективної реалізації, а також у разі правопорушення відновлення їх або поновлення правового становища суб'єкта трудового права, $\epsilon$ норми права та трудові договори. Вказані норми можуть виступати як гарантії реалізації трудових прав, які є доволі складним правовим явищем, адже проявляються у різних якостях на визначених стадіях правового регулювання, механізму охорони трудових прав і $є$ тією ланкою, що з’єднує її стадії.

Способами правового регулювання охорони трудових прав осіб з інвалідністю $є$ державне та договірне правове регулювання, а за рівнями його здійснення - централізоване та локальне. Державне правове регулювання охорони трудових праві осіб з інвалідністю здебільшого проявляється шляхом прийняття низки нормативно-правових актів, тому правовими засобами ііі здійснення виступають норми права. Договірне правове регулювання охорони трудових прав осіб з інвалідністю відображається в укладенні трудових договорів

Ключові слова: охорона та захист трудових прав осіб з інвалідністю, гарантії реалізації права на пращю, щчо надаються особам з інвалідністю.

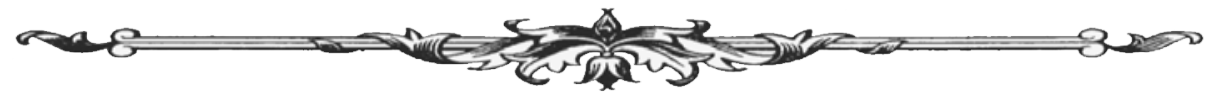


The concept of security and protection of labor rights of the disabled has been analyzed in this article. Protection of labor rights of the disabled can be considered both in a broad and narrow sense. Taking into account techniques of labor law and its specific manifestation, namely unity and differentiation of legal management of labor relationships, protection of labor rights of the disabled can be classified into general and specific protection. The general one is established, determined and applied to disabled persons as well as to the other employees. Protection of labor rights of the disabled is classified as specific when it is established, determined and applied only to employees who have a disability status. With regard to realities and discrepancies between protection of labor rights of the disabled as prescribed by the law, and its actual implementation, such protection of labor rights can be classified as legal and actual.

Legal phenomena oriented onto non-violation of labor rights of disabled employees, arrangement of conditions required for their unconstrained efficient implementation, also in case of violation in their renewal or resumption of a legal status of the subject of the labor law there are norms of law and labor contracts. Norms stated can act as guarantees for labor rights implementation which are quiet a complicated legal phenomenon as they develop differently at specific stages of legal regulation, mechanism of labor rights protection and are a link between the stages.

Protection of labor rights of the disabled can be regulated by the government or on a contract basis, according to its implementation level regulation can be central or local. Protection of labor rights of the disabled is regulated by the government via adoption of a number of legislative acts; therefore, it is put into effect by norms of law. Contractual legal regulation of protection of labor rights of the disabled is put into force by means of labor contracts.

Key words: protection and security of labor rights of the disabled, guarantees of enforcement of the right to work provided for disabled persosns.

Вступ. Питання охорони та захисту трудових прав осіб з інвалідіністю ніколи не залишалося осторонь уваги науковців. Це зрозуміло, осклільки, по-переше, сам зміст понять «охорона» та «захист» $є$ дискусійними, а, по-друге, правове регулювання праці осіб з інвалідністю як осіб, які потребують додаткових гарантій зайнятості та працевлаштування з розвитком ринкових відносин і погіршенням економічного становища в державі.ю актуалізується. Тому з'ясуванню змісту та розмежуванню вищезазначених категорій були присвячені праці багатьох науковців-трудовиків, значний внесок з-поміж яких зробили Н.Г. Александров, Т.Ю. Баришнікова, С.Я. Вавженчук, С.В. Венедиктов, М.I. Іншин, І.О. Костян, А.М. Лушніков, М.В. Лушнікова, O.I. Процевський, B.I. Щербина та ін. Не применшуючи цінності їх наукового досягнення, констатуємо потребу у виявленні особливостей охорони трудових прав осіб з інвалідністю, адже ця тематика фактично не виступала предметом спеціального наукового дослідження.

Постановка завдання. Метою статті є з'ясування змісту поняття охорона трудових прав осіб з інвалідністю, виявлення проблемних аспектів у цій сфері та можливих шляхів їх вирішення.

Результати дослідження. Насамперед з'ясуємо зміст понять «охорона трудових прав» і «захист трудових прав». Якщо звернутися до тлумачного словника сучасної української мови, то термін «охорона» - дія зі значенням охороняти, що означає оберігати когось, щось від небезпеки, загрози нападу, замаху тощо; стояти на варті біля чогось; вартувати, стерегти; забезпечувати, гарантувати недоторканість когось, чогось; оберігати від руйнування, пошкодження, знищення. Водночас термін «захист» тлумачиться як дія зі значенням захищати, що трактується як обороняти, охороняти кого- або що-небудь від чогось; стежити за недоторканістю, дотриманням (переважно законності) й активно діяти в цій сфері; брати участь у судовому процесі, обстоюючи інтереси обвинуваченого [1, с. 330]. Тут не можемо

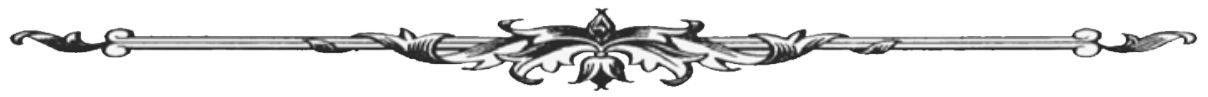


не відзначити, що у багатьох словниках вказані терміни трактуються як синоніми, що, на наш погляд, не відображає повною мірою сутність вказаних понять.

Як бачимо, поняття «захист» та «охорона» схожі за значенням, причому поняття охорони ширше і включає в себе перше. Захист - тільки один із проявів охорони, мета та завдання здійснення якої частково відображають кінцеву мету та завдання здійснення охорони. и не заперечуємо той факт, що наш погляд на сутність охорони трудових прав викликатиме дискусію, адже в науці трудового права немає єдиного погляду як на визначення вищезгаданих понять, так і на їх зміст. 3 огляду на вказане охорона та захист співвідносяться як ціле та частка. Охорону трудових прав прийнято розглядати як у широкому, так і у вузькому значенні. Так, С. Вавженчук охорону трудових прав у вузькому значенні (правову охорону трудових прав) пропонує розуміти як сукупність правових явищ і процесів, спрямованих на недопущення порушення трудових прав працівників, створення необхідних умов для їх безперешкодної ефективної реалізації, а також у разі правопорушення - відновлення їх або поновлення правового положення суб'єкта трудового права [2, с. 282]. Більше того, охорона трудових прав осіб з інвалідністю також може розглядатися у широкому й у вузькому розумінні. Беручи до уваги метод трудового права та його характерні прояви, зокрема єдність і диференціацію правового регулювання трудових відносин, охорону трудових прав осіб з інвалідністю, можна диференціювати на загальну та спеціальну. Загальною вона є та встановлюється, визначається та здійснюється для особи з інвалідністю нарівні з іншими найманими працівниками. Охорона трудових прав осіб з інвалідністю $є$ спеціальною, коли встановлюється, визначається та здійснюється тільки щодо працівників, яким встановлена група інвалідності. Враховуючи реалії сьогодення та невідповідність юридично визначеної охорони трудових прав осіб з інвалідністю з їі фактичною реалізацією на практиці, таку охорону трудових прав можна класифікувати на юридичну та фактичну.

Повертаючись до правової охорони трудових прав осіб з інвалідністю як сукупності правових явищ і процесів, відзначимо, що такими правовими явищами, виходячи 3 методу трудового права, є норми права та трудові договори (державне та договірне правове регулювання). Способами правового регулювання охорони трудових прав осіб з інвалідністю $\epsilon$ державне та договірне правове регулювання, а за рівнями його здійснення - централізоване та локальне. Державне правове регулювання охорони трудових праві осіб з інвалідністю здебільшого проявляється шляхом прийняття низки нормативно-правових актів, тому правовими засобами ії здійснення виступають норми права. Договірне правове регулювання охорони трудових прав осіб з інвалідністю відображається в укладенні трудових договорів. Не потрібно забувати, що умови трудових договорів, які погіршують становище працівників порівняно з нормами чинного трудового законодавства, визнаються недійсними (ст. 9 КЗпП України). Вказані норми можуть виступати як гарантії реалізації трудових прав, які є доволі складним правовим явищем, адже проявляються у різних якостях на визначених стадіях правового регулювання, механізму охорони трудових прав, є тією ланкою, що з'єднує ії стадії.

У юридичному словнику правові (спеціальні, юридичні) гарантії визначені як «закріплені в юридичних нормах правові засоби, які безпосередньо спрямовані на забезпечення правомірної поведінки учасників тих чи інших суспільних відносин або нормального функціонування того чи іншого інституту». Засобами, за допомогою яких створюються умови для досягнення окресленої мети, в юридичних джерелах називають різні правові явища: ними можуть бути правові норми, принципи права, охорона суспільних відносин шляхом установлення міри обов'язкової поведінки суб'єктів, можливість судового захисту, відновлення порушених прав, юридична відповідальність тощо [3]. 3 огляду на вказане цілком прийнятною є позиція К.Ю. Мельник, зокрема щодо «під юридичними гарантіями прав людини слід розуміти встановлені державою норми права, які спрямовані на захист прав людини, а також відповідну діяльність уповноважених органів, направлену на реалізацію цих норм» [4, с. 19].

Юридичні гарантії у трудовому праві - це такі правові норми, що визначають специфічні юридичні засоби, умови і порядок реалізації трудових прав, їх правової охорони та захисту.

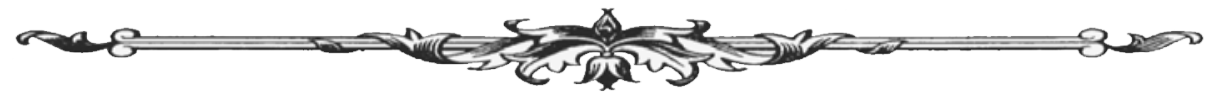


3 огляду на зазначене з’ясуємо, яким чином проявляється охорона трудових прав осіб з інвалідністю, які вступають у трудові правовідносини, перебувають у них чи їх припиняють. У КЗПП України в розділі «Охорона праці» міститься ст. 172, присвячена застосуванню праці осіб з інвалідністю. У цій статті зазначається, що у випадках, передбачених законодавством, на власника або уповноважений ним орган покладається обов'язок організувати навчання, перекваліфікацію і працевлаштування осіб з інвалідністю відповідно до медичних рекомендацій, встановити на їх прохання неповний робочий день або неповний робочий тиждень і створити пільгові умови праці. Залучення осіб з інвалідністю до надурочних робіт і робіт у нічний час без їх згоди не допускається. Не потрібно плутати охорону праці осіб з інвалідністю й охорону трудових прав вказаної категорії осіб у трудових правовідносинах. Сама ж охорона праці відповідно до ст. 1 Закону України «Про охорону праці» визначається як система правових, соціально-економічних, організаційно-технічних, санітарно-гігієнічних і лікувально-профілактичних заходів і засобів, спрямованих на збереження життя, здоров’я і працездатності людини у процесі трудової діяльності. Так, відповідно до законодавчих норм охорона праці дозволятиме уникнути ушкодження здоров'я, його втрати або втрати взагалі життя працівника. Термін «охорона» вказує на здійснення певних превентивних заходів та засобів з метою досягнення кінцевої мети - збереження життя та здоров’я осіб з інвалідністю. Саме поняття охорони праці у науці трудового права прийнято розглядати як в широкому, так і вузькому розумінні. У широкому значенні охорону праці потрібно розуміти як сукупність правових норм, які регулюють відносини праці загалом (надшироке значення охорони праці). Такими нормами, на думку У.П. Бек, можна вважати норми кримінального, адміністративного права, права соціального забезпечення, які визначають види та порядок юридичної відповідальності за порушення норм охорони праці, умови страхування і відшкодування в разі настання нещасних випадків на виробництві та професійних захворювань [5, с. 8]. Водночас, як слушно зазначає Н.Я. Бутинська, у трудовому праві це будуть тільки відносини найманої праці. До них вона відносить норми щодо необгрунтованої відмови у прийнятті на роботу чи незаконного звільнення, норми, що встановлюють мінімальний час відпочинку (наприклад, тривалість щорічної основної відпустки не менше 24 календарних дні), максимальну тривалість робочого часу (тривалість робочого тижня не повинне перевищувати 40 годин), встановлення доплат і надбавок за роботу у шкідливих та важких умовах праці тощо. Натомість сукупність норм, що регулюють встановлення безпечних і нешкідливих умов праці з метою запобігання негативного впливу на життя та здоров’я працівників, потрібно розглядати як охорону праці у вузькому значенні [6, с. 84].

Зауважимо, що проект ТК України в частині прав осіб з інвалідністю характеризується: відображенням тих загальних прав і гарантій, які містить КЗПП України й окремі спеціальні закони; наділенням осіб з інвалідністю загальним комплексом прав, без урахування особливостей їх праці; не врахуванням повною мірою норм Конвенції ООН про права інвалідів; відсутністю вимог і норм про громадський контроль із питань праці громадських організацій інвалідів. За таких обставин очевидною є висока ймовірність того, що питання праці людей з інвалідністю матимуть формальний характер, у разі ухвалення парламентом ТК, а відтак їх участь на ринку праці буде декларативною [7].

Звісно, окрім КЗпП України, правове регулювання праці осіб з інвалідністю здійснюється за допомогою низки нормативно-правових актів та актів договірного характеру (безпосередньо укладеного трудового договору $з$ працівником 3 інвалідністю, актами соціального партнерства). Серед нормативно-правових актів, присвячених цьому питанню, визначальне місце займає Закон України «Про основи соціальної захищеності осіб з інвалідністю», хоч предметом його правового регулювання $є$ не безпосередньо трудові відносини 3 даною категорією осіб. Так, відповідно до зазначеного Закону з метою реалізації творчих і виробничих здібностей осіб з інвалідністю та з урахуванням індивідуальних програм реабілітації їм забезпечується право працювати на підприємствах, в установах, організаціях, а також займатися підприємницькою та іншою трудовою діяльністю, яка не заборонена законом. Забезпечення прав осіб з інвалідністю на працевлаштування й оплачувану роботу, в т. ч.

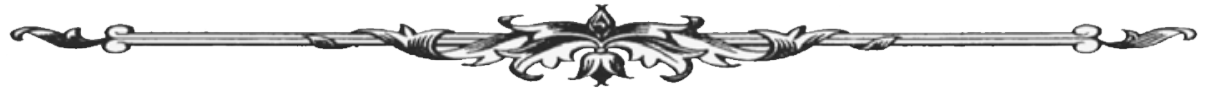


з умовою про виконання роботи вдома, здійснюється шляхом їх безпосереднього звернення до підприємств, установ, організацій чи до державної служби зайнятості.

Підбір робочого місця здійснюється переважно на підприємстві, де настала інвалідність, з урахуванням побажань особи з інвалідністю, наявних у неї професійних навичок і знань, а також рекомендацій медико-соціальної експертизи.

Відповідно до ст. 14 Закону України «Про зайнятість населення» особи з інвалідністю, які не досягли пенсійного віку, належать до категорії осіб, яким надаються додаткові гарантії сприяння у працевлаштуванні. Сутність цих гарантій полягає у встановленні нормативу їх працевлаштування шляхом визначення квоти та броні робочих місць.

Юридичні гарантії, що надаються особам з інвалідністю при працевлаштуванні, - це система визначених нормами трудового права юридичних гарантій, які випливають із реалізації права на повну зайнятість та встановленої процедури укладення трудового договору. Вказану групу гарантій слід класифікувати на дві групи: 1) загальні гарантії реалізації права на працю при працевлаштуванні, передбачені для всіх громадян, якими особи з інвалідністю володіють нарівні з іншими; 2) додаткові гарантії реалізації права на працю осіб з інвалідністю, що надаються їм при працевлаштуванні.

Гарантіями права на працю осіб з інвалідністю, що надаються їм при виконанні ними трудової функції, $є$ : 1) обов’язок роботодавця надати працівнику зі зниженою працездатністю робоче місце, що відповідає вимогам законодавства й рекомендаціям МСЕК; 2) законодавчо встановлена більша тривалість щорічної основної відпустки й додаткової відпустки без збереження заробітної плати порівняно з іншими працівниками. Щорічна основна відпустка надається незалежно від наявності шестимісячного безперервного стажу роботи на відповідному підприємстві, установі, організації чи у фізичної особи, яка використовує найману працю відповідно до законодавства; 3) заборона залучення осіб зі зниженою працездатністю до робіт у нічний час і надурочних робіт без їх згоди. Залучення цієї категорії працівників до вказаних робіт відбувається за умови, що це не суперечить медичним рекомендаціям; 4) законодавчо встановлений обов'язок власника або уповноваженого ним органу перевести працівників, які потребують за станом здоров'я надання легшої роботи, за їх згодою, на роботу відповідно до медичного висновку; 5) заборона тимчасового переведення власником або уповноваженим ним органом працівника на іншу роботу, не обумовлену трудовим договором, якщо вона протипоказана йому за станом здоров'я [8, с. 136].

Юридичні гарантії, що надаються особам з інвалідністю у процесі припинення трудового договору - це система визначених нормами трудового права юридичних гарантій, які виникають у процесі припинення дії трудового договору [9, с. 14]. Загальними гарантіями права на працю осіб з інвалідністю, що надаються їм при припиненні трудового договору, є: а) наявність законних підстав для припинення трудового договору; б) дотримання встановленого порядку звільнення з роботи. Додатковими гарантіями права на працю осіб з інвалідністю, що надаються їм при припиненні трудового договору є: 1) обов’язок власника чи уповноваженого ним органу розірвати строковий трудовий договір на вимогу працівника в разі його хвороби або інвалідності; 2) переважне право на залишення на роботі при вивільненні працівників у зв'язку із змінами в організації виробництва і праці за рівних умов продуктивності праці і кваліфікації для працівників, які дістали на цьому підприємстві, в установі, організації трудове каліцтво або професійне захворювання, а також учасників бойових дій, осіб зі зниженою працездатністю внаслідок війни та осіб, на яких поширюється чинність Закону України «Про статус ветеранів війни, гарантії їх соціального захисту», а також осіб зі зниженою працездатністю з числа учасників ліквідації наслідків аварії на Чорнобильській AEC і потерпілих від Чорнобильської катастрофи, щодо яких встановлено причинний зв'язок зниження працездатності з Чорнобильською катастрофою, хворі внаслідок Чорнобильської катастрофи на променеву хворобу [8, с. 137].

Висновки. На основі викладеного ми дійшли таких висновків. Охорона трудових прав осіб з інвалідністю може розглядатися як у широкому, так і у вузькому розумінні. Беручи до уваги метод трудового права та його характерні прояви, зокрема єдність і диференціацію

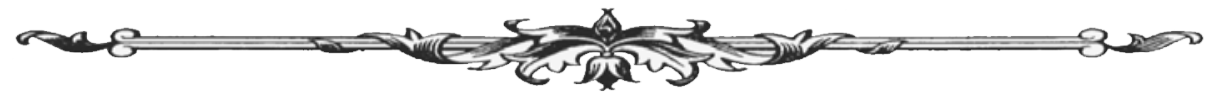


правового регулювання трудових відносин, охорону трудових прав осіб з інвалідністю, можна диференціювати на загальну та спеціальну. Загальною вона є та встановлюється, визначається і здійснюється для особи з інвалідністю на рівні з іншими найманими працівниками. Охорона трудових прав осіб з інвалідністю є спеціальною, коли встановлюється, визначається та здійснюється тільки щодо працівників, яким встановлена група інвалідності. Враховуючи реалії сьогодення та невідповідність юридично визначеної охорони трудових прав осіб з інвалідністю з їі фактичною реалізацією на практиці, таку охорону трудових прав можна класифікувати на юридичну та фактичну. Правовими явищами, спрямованими на недопущення порушення трудових прав працівників з інвалідністю, створення необхідних умов для їх безперешкодної ефективної реалізації, а також у разі правопорушення відновлення їх або поновлення правового становища суб'єкта трудового права є норми права та трудові договори. Способами правового регулювання охорони трудових прав осіб з інвалідністю є державне та договірне правове регулювання, а за рівнями його здійснення - централізоване та локальне. Державне правове регулювання охорони трудових праві осіб з інвалідністю здебільшого проявляється шляхом прийняття низки нормативно-правових актів, тому правовими засобами іiі здійснення виступають норми права. Договірне правове регулювання охорони трудових прав осіб з інвалідністю відображається в укладенні трудових договорів.

\section{Список використаних джерел:}

1. Сучасний тлумачний словник української мови / за заг. В.В. Дубічинського. Харків : ВД «ШКОЛА», 2009. 1008 с.

2. Вавженчук С. Сдність та диференціація мір превентивної охорони, захисту трудових прав та мір трудо-правової відповідальності. Публічне право. 2015. № 3 (19). С. 278-283.

3. Вавженчук С.Я. Охорона та захист трудових прав працівників : підручник. Харків : Право, 2016. 560 с.

4. Мельник К.Ю., Бабенко А.О. Проблеми юридичних гарантій трудових прав працівників при укладенні, зміні та розірванні трудового договору : монографія. Харків : Харків. нац. ун-т внутр. справ, 2016.

5. Бек У.П. Правове регулювання охорони праці в Україні: теоретичний аспект : автореф. дис. ... канд. юрид. наук : 12.00.05 / Львівський нац. у-т ім. Івана Франка. Львів, 2013. 18 с.

6. Бутинська Р.Я. Охорона праці як функція трудового права. Соцііально-правові студіi. 2019. Вип. 2 (4). С. 82-87.

7. Костюк В.Л. Кодифікація трудового законодавства у контексті прав осіб з інвалідністю: проблеми, новації та перспективи. URL: http://ekmair.ukma.edu.ua/bitstream/handle/. C. 87-92.

8. Козуб І.Г. Правове регулювання праці осіб зі зниженою працездатністю : монографія. Чернівці : Чернівецький нац. ун-т, 2010. 152 с.

9. Яцкевич I.I. Правове регулювання юридичних гарантій реалізації особою права на працю : автореф. дис. ... канд. юрид. наук : 12.00.05. Київ, 2016. 21 с.

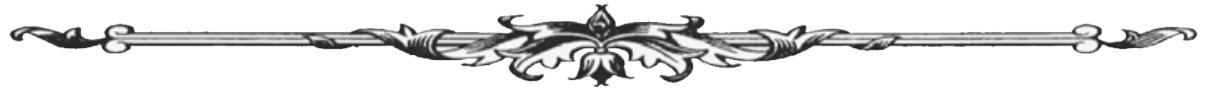

